\title{
ГРОМАДСЬКА ТА ПРИВАТНА ІНІЦАТИВА У РОЗВИТКУ ПОЧАТКОВОЇ ОСВІТИ В МАРІУПОЛІ ТА МАРІУПОЛЬСЬКОМУ ПОВІТІ (ДРУГА ПОЛОВИНА ХІХ СТ.)
}

Тенденції сучасної вітчизняної історикопедагогічної науки характеризуються віддзеркаленням генези становлення та розвитку освітньої теорії та практики окремих регіонів України, що розкриває особливості розв'язання освітніх завдань у межах різних етнічних культур. Історія педагогіки інтегрує, накопичує й інтерпретує висновки науковців, отримані у межах локальних досліджень, з метою забезпечення комплексного, цілісного підходу у вивченні історичного минулого як невід' ємної складової вітчизняної культури.

На посиленні виховного чинника національної культури акцентовано у Національній стратегії розвитку освіти в Україні на період до 2021 року (2013); Законах України «Про освіту» (2017), «Концептуальних засадах реформування середньої освіти (Концепції нової української школи)» (2017), інших нормативних документах МОН України. Зокрема, у Національній стратегії розвитку освіти в Україні на період до 2021 року наголошується на необхідності побудови ефективної системи національного виховання на засадах загальнолюдських, полікультурних, громадянських цінностей, забезпечення фізичного, морально-духовного, культурного розвитку дитини, формування соціально зрілої творчої особистості, громадянина України і світу [11].

У зазначеному контексті особливої значущості набуває проблема оптимального поєднання класичної спадщини та сучасних досягнень наукової думки, використання позитивних освітніх надбань у межах усієї держави та окремого їі регіону. Грунтовне вивчення, об'єктивний аналіз i творче осмислення досвіду, накопиченого в Україні на регіональному рівні протягом різних історичних періодів, сприятимуть упровадженню кращих здобутків освіти в сучасну педагогічну теорію та практику, звільнять від заангажованого висвітлення подій, дадуть змогу позитивно впливати на модернізацію змісту національної освіти на засадах полікультурності.

Окремою складовою вітчизняної культури $€$ історія становлення і розвитку освітньої теорії та практики Півдня України, що від самого початку заселення у межах Новоросійської губернії як адміністративної одинищі був поліетнічним регіоном.

Історія становлення та розвитку початкової та середньої освіти на території Півдня України у цілому та Приазовського регіону зокрема почала вивчатися наприкінці XIX - на початку XX ст. У роботах Г. Фальборка, В. Чарнолуського, М. Чехова надано характеристику основних типів народних шкіл, розкрито провідну роль земської школи в просвіті сільського населення, наведено фактичний матеріал про умови життя, педагогічну і просвітницьку діяльність педагогів.

За радянських часів дослідники не приділяли достатньої уваги висвітленню особливостей освітньої теорії та практики Півдня України 3 ідеологічних причин. Інтерес до проблеми зріс на початку XXI ст. У роботах Н. Бацак, Б. Бровка, С. Вишневського, О. Мармазової, Л. Рябовола, А. Форостян, Т. Шушари та ін. дослідників розкрито соціально-культурні передумови становлення та розвитку регіонального шкільництва; досліджено генезис змісту освіти, що надавалася навчальними закладами різних типів; виокремлено й обгрунтовано основні тенденції розвитку системи освіти регіону з урахуванням його етнічних особливостей.

С. Арабаджі, С. Новіковою, І. Шуміловою визначено соціально-економічні, політичні та поліетнічні витоки розвитку приазовської земської школи; висвітлено зміст просвітницької діяльності повітових земств, їхню роль у забезпеченні професійної підготовки вчителів.

Історичному аналізу проблем національних меншин Приазов'я присвячено дослідження вітчизняних та зарубіжних науковців. Зокрема, у працях І. Задерейчука, О. Правдюк розкрито соціально-педагогічні умови становлення освіти німців та менонітів; обгрунтовано етапи ії розвитку, розкрито особливості функціонування окремих компонентів освітньої системи (зокрема початкових шкіл); показано динаміку розвитку освіти німців та менонітів на території Приазов'я 
протягом XIX - початку XX століття. У наукових розвідках С. Пачева розкрито проблему організації освіти у колоніях приазовських болгар, діяльність сільських громад щодо розбудови системи початкової освіти, здійснено аналіз рівня писемності болгарського населення регіону.

На сучасному етапі історіографія проблеми становлення освіти у регіоні збагатилася дослідженнями Н. Терентьєвої, А. Гедьо, Л. Якубової, в яких розкривається історія греків Приазов'я. Науковцями охарактеризовано зміст діяльності грецьких земств, розкрито особливості становлення земських шкіл, визначено соціальноекономічні й культурно-історичні чинники освітньої діяльності грецької етнічної спільноти.

Проблеми становлення і розвитку освіти у Маріупольському повіті в контексті загальноісторичного розвитку Приазов'я розкрито у роботах Л. Якубової, О. Сараєвої, М. Подгайко, Л. Яруцького та ін. Важливими у зазначеному контексті є дослідження Д. Лебєдєва, в яких висвітлено особливості функціонування церковноприходських шкіл в системі початкової освіти Катеринославської губернії. Автором детально розкрито історію створення зазначених освітніх закладів у Маріупольському повіті в кінці XIX - на початку XX століття; проаналізовано зміст, форми та методи навчання, подано значний фактичний матеріал, що ілюструє особливості організації освітнього процесу в церковноприходських школах.

Проте роботи зазначених вище науковців носять узагальнювальний характер та не відображають генезу становлення початкової освіти, не розкривають цілеспрямовано роль громадськості у розвитку початкових шкіл в Маріуполі та Маріупольському повіті.

Відтак, метою статті $є$ аналіз діяльності повітового земства, громадськості та приватних осіб у розвитку початкової освіти в Маріуполі та Маріупольському повіті протягом другої половини XIX ст.

Термін «Південь України» увійшов до ужитку відповідно до адміністративно-територіальної реформи Петра I (1708 р.) й використовувався на позначення територій Катеринославської, Таврійської і Херсонської губерній, які об'єднувались у Новоросійсько-Бесарабське генерал-губернаторство. Загальний процес територіально-адміністративного облаштування цих територій супроводжувався процесами економічної інкорпорації південноукраїнських земель до складу Російського імперії, що включали в себе заселення та господарське освоєння степової України $[14$, с. 276$]$.

Початок колонізації Південної України проходив у двох напрямках: внутрішній обумовлювався переселенням національних меншин виключно в межах Російської імперії; зовнішній заселенням Південної України вихідцями з європейських держав. За період з 1782 по 1858 рр. на південь України переселилось 3 північноукраїнських, російських та білоруських губерній 904000 осіб, з них в Катеринославській губернії осіло 310000 [17, с. 176]. На кінець XVIII ст. $85 \%$ населення цих територій складали українщі, 3 \% росіяни, $22 \%$ - німці, греки, болгари, поляки, білоруси, турки, вірмени, татари та ін. населення [7].

Протягом 100 років інтенсивного заселення Південноукраїнського регіону кількість етносів на його території сягнула більше 50. За даними першого перепису населення 1897 р. найбільш чисельними етносами на Півдні України були: українці - 56,1 \%, росіяни - 21,4 \%, євреї - 7,6 \%, німці - 4,4 \%, татари - 3,4 \%, молдавани - 2,5\%, греки - 1,2 \%, болгари - 1,1 \% та інші [13, с. 24-25].

Такою самою поліетнічністю характеризувався Маріупольський повіт (табл. 1) [13].

\section{Етнічний склад населення Маріупольського повіту} відповідно до визнання рідної мови (1897 р.)

\begin{tabular}{|c|c|c|}
\hline \multirow{2}{*}{ Групи мов } & \multicolumn{2}{|c|}{ Абсолютний показник населення } \\
\hline & Чоловіки & Жінки \\
\hline Українська & 60351 & 56855 \\
\hline Російська & 19407 & 16284 \\
\hline Білоруська & 942 & 755 \\
\hline Польська & 288 & 240 \\
\hline Слов'янські мови & 104 & 20 \\
\hline Литовсько-латишські мови & 37 & 4 \\
\hline Романські мови & 184 & 84 \\
\hline Німецька & 9412 & 9552 \\
\hline Англійська & 74 & 16 \\
\hline Індоєвропейські мови: & 24730 & 23655 \\
\hline - грецька & 24662 & 23628 \\
\hline - вірменська & 44 & 16 \\
\hline - циганська & 28 & 11 \\
\hline Сврейська & 5150 & 5141 \\
\hline Фінська & 5 & 0 \\
\hline Турецько-татарська & 10608 & 10141 \\
\hline Мову не вказано & 3 & 0 \\
\hline
\end{tabular}


За «Положенням про початкові народні училища» (1864 р.) у Російської імперії було закладено основи уніфікованої системи державної початкової школи, до якої належали:

1) навчальні заклади Міністерства народної освіти:

- парафіяльні училища в містах і селах, що утримувались коштом місцевих громад і частково за рахунок благодійницьких пожертв приватних осіб;

сувалися приватними особами різних станів;

2) училища різних міністерств і відомств (наприклад, міністерства державного майна, внутрішніх справ тощо);

3) навчальні заклади духовного відомства: міські й сільські церковнопарафіяльні училища;
4) всі недільні школи (державні, громадські або приватні) для навчання дорослого населення ремісничого й робітничого станів [6, c. 116].

Проте, поліетнічна картина регіону обумовила виникнення своєрідної системи підпорядкування закладів початкової освіти (рис. 1). Фактично існувало дві системи початкової освіти, що підпорядковувалися різним міністерствам: Міністерству народної освіти та Міністерству внутрішніх справ. Окремим органом управління було духовне відомство, що здійснювало керівництво церковнопарафіяльними школами та у взаємодії 3 Міністерством народної освіти опосередковано впливало на діяльність не підпорядкованих йому закладів освіти.

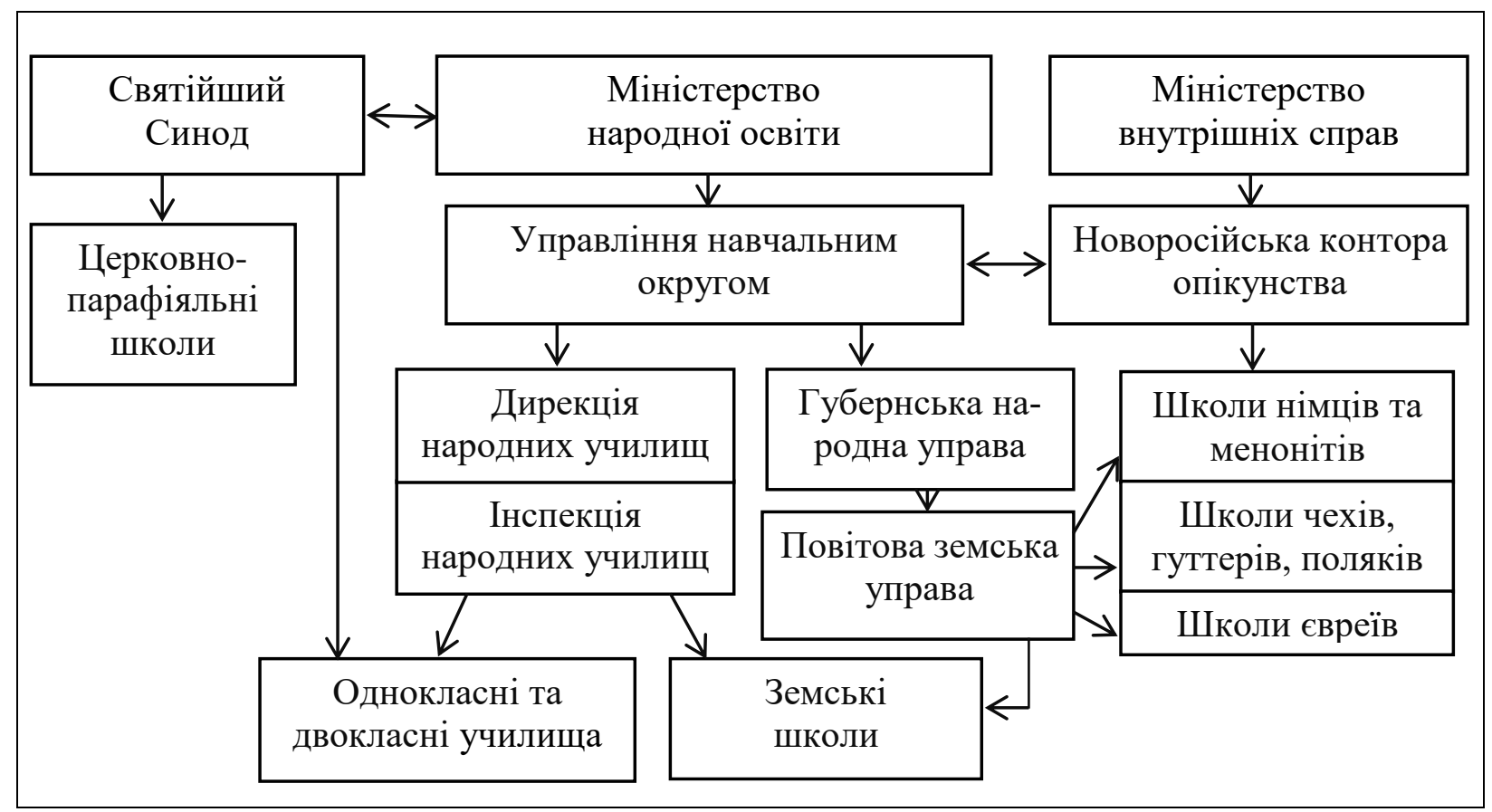

Рис. 1. Система управління освітою Півдня Украӥни XIX cm.

Система початкової освіти етно-конфесійних спільнот на території Маріупольського повіту мала певні особливості, пов'язані 3 політикою царського уряду щодо переселенців різних національностей. Зокрема німці, меноніти, гуттери мали від царського уряду особливі привілеї, оскільки розглядалися як носії новітніх прогресивних технологій вирощування сільськогосподарської продукції.

Керівництво державною початковою школою здійснювалось повітовими і губернськими училищними радами, до складу яких, крім чиновників Міністерства народної освіти, духовенства, входили представники органів місцевого самоврядування - земств і міської думи. Усі рішення стосовно організації або закриття народ- них училищ, затвердження навчальних програм, призначення на посади вчителів приймались виключно училищною радою. Голова повітової училищної ради був виборним.

Культурно-освітні питання Маріуполя знаходились у юриспруденції виконавчого органу думи - Маріупольської міської управи. На початку 1869 р. Маріупольські повітові збори обрали місцевий виконавчий орган - земську управу. Понад 50 років вона здійснювала керівництво в усіх сферах господарського життя повіту: заснуванні і управлінні закладів освіти, охорони здоров'я, благодійницьких установ, організації фінансового, культурного і економічного розвитку Маріупольського повіту.

Державні початкові училища об'єднувались 
як за єдиним способом управління та загальним курсом навчання. 3 метою забезпечення урядового контролю за роботою народних училищ «Положення» 1864 р. проголошувало вимогу використання в початкових народних училищах навчальних посібників, схвалених Міністерством народної освіти і духовним відомством [17]. Обсяг вивчення обов'язкових предметів (читання, письмо, перші чотири дії арифметики та церковний спів) обмежувався елементарною грамотністю, мовою викладання в початковій школі по всій території багатонаціональної Катеринославської губернії, як і в імперії у цілому встановлювалася російська. Цьому сприяла агресивна русифікаторська політика царського уряду.

Найжорстокішим 3 усіх протиукраїнських заходів став Емський указ від 18 травня 1876 р. (створений таємним царським радником М. Юзефовичем), який забороняв увезення будь-яких українських книжок і брошур із-за кордону; видання українських творів та переказів; друкування слів українською мовою біля нот, влаштування українських вистав, читання для народу, організацію народних шкіл з українською мовою навчання.

Найбільше сприяння уряду отримували церковнопарафіяльні школи, головне призначення яких полягало у забезпеченні народної освіти селян. Передумовою відкриття таких шкіл за чинним законодавством була домовленість між сільською громадою та місцевими священнослужителями [5, с. 62].

Про місце церковноприходських шкіл в освітньому просторі країни свідчать такі статистичні дані: у 1915 р. налічувалося 40530 церковно-приходських шкіл, що складало майже третину $(32,8 \%)$ всіх освітніх закладів країни [4, с. 34]. У Маріуполі найбільш відомою була церковноприходська школа (1864-1877 рр.), відкрита священиком Харлампієвського собору Д. Текеджи, що користувалася популярністю у населення грецького походження [6, с. 119].

Проте, церковнопарафіяльні школи не стали домінантним типом закладів початкової освіти на Півдні України, що пояснюється різним віросповіданням численних етнічних груп, які населяли Приазов'я. Катеринославська губернія станом на 1886 р. нараховувала 45 земських та лише 13 церковно-приходських шкіл [17].

Для багатьох переселенців була характерна послідовна тенденція до автономії школи та високий ступінь самоорганізації громад у вирішенні питань освіти (вплив російської системи освіти на колонії німців, менонітів, євреїв мав організаційно-адміністративний характер і полягав у підпорядкуванні етноконфесійних закладів Міністерству внутрішніх справ (3 80-х рр. XIX ст. - Міністерству народної освіти), поступо- вому введенні квот на навчання дітей внутрішніх переселенців (етнічних українців та росіян) та запровадженню до навчальних програм російської мови).

3 огляду на зазначене, провідну роль у розбудові початкової світи в регіоні почали відігравати земські школи, головною перевагою яких було спрямування освітнього курсу на практичні інтереси населення та безкоштовність навчання $[9$, с. 13$]$.

Удосконалення освіти, доступної та близької для народу, було одним 3 найважливіших завдань Маріупольського повітового земства. Першу земську школу було відкрито під патронатом М. Корфа у с. Мала Янісоль (1869 р.). У Маріупольському повіті, населення якого перевищувало 100000 осіб у 1889-1890 навчальному році працювало 72 земські школи, в яких здобували початкову освіту 7312 учнів (5 522 хлопчиків та 1790 дівчаток). Найбільша кількість учнів більше 200 на школу - приходилася на грецькі села Богатир, Камар, Мангуш, Новий Янісоль та Ялту. В російських селах найбільша кількість учнів приходилася на дві школи у Новоспасівці. Найменша кількість учнів (близько 30 на школу) зафіксовано у німецьких селах [18].

Земські школи працювали за єдиною системою організації: мали поділ на декілька відділень - за роками навчання (хлопчики і дівчатка могли навчалися як спільно, так і окремо). Усі діти сиділи разом в одній класній кімнаті. Зазвичай двом відділенням викладач пропонував певні самостійні завдання 3 читання, письма або математики, а 3 третім відділенням працював, пояснюючи новий матеріал або проводячи усне опитування. Для таких групових занять було вироблено спеціальну методику викладання [8, с. 74].

Зразкова програма чотирирічної земської школи містила такі дисципліни: Закон Божий, церковнослов'янська мова, читання, письмо, арифметика, предметні бесіди, історія, географія, світознавство, малювання і креслення, спів, гімнастика (рукоділля для дівчаток). Головним предметом у земській початковій школі була російська мова. Спершу діти читали короткі і нескладні тексти, потім переходили до значних за обсягом оповідань. У межах навчання письму вчителі спочатку обмежувалися проведенням диктанту, в 90-х рр. XIX ст. стали практикувати письмовий переказ. На початку XX ст. в деяких повітових школах учні випускних відділень вже писали твори на задані або вільні теми [4, с. 67].

У цей час у повіті також діяли початкові школи, що задовольняли освітні потреби представників певних етнічних груп. Станом на 1870 р. в 25 грецьких селах діяло вже 21 земське училище, і їхня кількість, як і число дітей, що отримували можливість здобувати в них освіту, 
невпинно зростала.

Вагомою складовою діяльності Маріупольського повітового земства була підтримка єврейської спільноти. За сприяння земства у 1870 р. було відкрито безкоштовну Талмуд-тору для єврейських дітей з бідних родин. Очолили школу представники Маріупольського єврейського товариства А. Оргуз та I. Расін. У школі викладалися: єврейська мова, російська грамота, Біблія й арифметика. Навчальний заклад розміщувався в будинку для молитов, де кожного року навчалося близько 80 дітей. Окрім того Маріупольське повітове земство взяло на себе обов'язок безкоштовно забезпечувати учнів Талмуд-тори одягом і взуттям [2].

Окремою складовою частиною системи елементарної освіти Катеринославщини були закриті заклади освіти німців та менонітів. Найпоширенішим типом німецьких та менонітських закладів світи була початкова школа, що створювалася в кожній колонії та мала яскраво виражене релігійне спрямування й виконувала завдання надання загальної освіти та закладання міцних засад менонітського віровчення. У 1899 р. на території Північного Призов'я працювало 35 німецьких початкових шкіл, де здобували освіту діти від семи років. Заняття проводилися з 8 до 12 та 3 14 до 16 годин [1].

Домінування елементарного змісту освіти у початкових школах пояснюється культурною ізоляцією менонітських громад, що зумовила формування стагнації освітньої практики менонітів. Висока результативність освітніх зусиль у зазначених закладах зумовлювалася стійкими релігійними позиціями освіти (дітей готували до обряду конфірмації, обов'язковою умовою якого було самостійне читання дитиною релігійного тексту), ії культурно-духовною спрямованістю [15].

Отже, громадська ініціатива у створенні закладів початкової освіти відігравала в освітньому полі Північного Приазов' я значущу роль. Завдяки активному сприянню Маріупольського земства у повіті протягом 1867 р. було відкрито 6 початкових училищ, протягом 1868 р. - 14, 1869 р. - 6, 1870 р. - 7. Станом на 1870 р. у 25 грецьких селах діяло вже 21 земське початкове училище. У 1896 р. у повіті працювало 28 грецьких та 35 німецьких закладів початкової освіти [12].

Завдяки приватній ініціативі в Маріупольському повіті було відкрито 7 єврейських громадських шкіл, 1 Талмуд-тора. 26 хедерів. Всього ж в Маріуполі та повіті до кінця XIX ст. працювали 213 початкових навчальних закладів, що знаходилися у веденні різних міністерств і відомств $[17$, c. 79$]$.

Кількість дітей етно-конфесійних меншин, які бажали навчатися рідною мовою, удвічі перевищувала кількість учнів у російських класах тих самих училищ. Але внаслідок проваджуваної 3 боку уряду і місцевої влади русифікаторської політики, через відсутність будь-якої підтримки 3 боку училищних рад й земських органів та за нестачі необхідних методик і підручників національними мовами, а також $з$ причини достатньої кількості кваліфікованих учителів, викладання мов етно-конфесійних меншин у народних училищах Маріупольського повіту поступово припинилося [17 с. 166].

На цьому тлі значну роль у розвитку початкової освіти відіграла приватна ініціатива. У Маріуполі успішно функціонували училища I. Волосова (1888 р.), в якому здобували освіту 15 хлопчиків, та Ф. Волосової (1889р.) на 8 учнів. Щорічна платня за навчання становила 40 руб. [10].

У 1853 р. у Маріуполі було відкрито першу міську жіночу початкову школу. Ініціаторкою ї відкриття була дочка колишнього вчителя приходського училища Кунахова. У створеному нею закладі освіти, що відповідав усім міністерським вимогам, викладали Закон Божий, російську мову, арифметику, краснопис, рукоділля і танці. У перший рік у школі навчалося 12 учениць, у наступний - вже 40. Не менш популярним у жителів міста був пансіон Померанцевої, відкритий у 1857 р., та трьохкласний дівочий пансіон О. Медведської, відкритий у 1863 р. [3].

Всього у Маріупольському повіті до кінця XIX ст. працювали 213 закладів початкової освіти, що підпорядковувалися різним міністерствам i відомствам [9, с. 79]. Таке зростання чисельності закладів початкової освіти загострювало проблему забезпечення шкіл кваліфікованими вчительськими кадрами. Зазначена проблема у межах закладів освіти різного підпорядкування мала різні варіанти вирішення. Зокрема, Маріупольське земство само сплачувало народному вчителю заробітну плату у розмірі 360-474 руб. на рік. $[3$, c. 80$]$.

У межах менонітської етноконфесійної спільноти, проблема забезпечення шкіл педагогічними кадрами вирішувалася шляхом запрошення вчителів 3-за кордону, підготовки педагогічних кадрів за кордоном на кошти громад, підготовки вчителів для початкових шкіл у центральних училищах, підвищеної підготовки педагогів для центральних шкіл у Гальбштадтському та Хортицькому училищах. Отримана у центральних й педагогічних училищах освіта часто доповнювалася педагогічною освітою, отриманою в університетах Німеччини, Швейцарії, російських університетах, інститутах для вчителів [15].

Вирішення завдання професійної підготовки вчителів для єврейських закладів початкової освіти було покладене на Житомирський єврейський вчительський інститут (1873-1885 рр.), який був єдиним на території України вишем, 
що здійснював професійну підготовку вчителів для єврейських шкіл і училищ. Зазначений заклад освіти давав грунтовні знання з загальноосвітніх предметів, проте не забезпечував спеціальної підготовки: рівень викладання навчальних дисциплін, що відображали суто національну складову освіти (єврейська мова, історія та культура єврейського народу тощо), був низьким [16].

О. Сараєва, аналізуючи діяльність земства Донбасу в системі владних і суспільних відносин пореформеної доби, наводить дані Маріупольського повітового земства за 1913 р., що дають можливість зробити висновки щодо кадрового складу педагогів. Того року в земських школах повіту працював 251 учитель. 3 них закінчили: педагогічний клас жіночої гімназії 92 особи, педагогічний клас єпархіального жіночого училища - 39, учительську семінарію - 53. Інші педагоги склали екстерном іспит на звання вчителя початкової школи. Більшість учителів, які працювали в школах міста і повіту, отримали педагогічну освіту в навчальних закладах Маріуполя - Маріїнській жіночій гімназіі, жіночому єпархіальному училищі і вчительській семінарії [17, с. 72].

Наведені факти дозволяють зробити висновок про значущість земської та приватної ініціативи у розвитку початкової освіти в Північному Приазов'ї. Провідна роль у розвитку початкової освіти зазначеного регіону у другій половині XIX століття належить Маріупольському повітовому земству. Формуючи освітню політику 3 урахуванням місцевих потреб, активно співпрацюючи 3 низовими органами самоврядування - сільськими сходами та органами самоврядування міста Маріуполя, етноконфесійними громадами, що населяли регіон - Маріупольське земство за короткий термін змогло створити відносно розгалужену систему освіти, що відображала освітні інтереси етносів полікультурного регіону.

\section{СПИСОК ВИКОРИСТАНИХ ДЖЕРЕЛ}

1. Ермолов В. В. Особенности системы образования в национальных школах Российской империи: немецкие школы. Общество. Среда. Развитие. 2009. № 3. С. 81-88.

2. Сфимов Д. В. Земська реформа та ії вплив на розвиток народної освіти Донбасу у другій половині XIX - на початку XX ст. Педагогічні науки: теорія, історія, інноваційні технології. 2016. № 2(56). C. 253-262.

3. Заслушан доклад комиссии для разработки оснований сооружения народных школ. 1874 г. Систематический сборник постановлений Мариупольского уездного земства с 1869 по 1913 гг.: в 2-х т. Москва: Элек.-Типогр. Бр. Э. и А. Гольдрин, 1916. Т. 2. С. 80-81.

4. Звягинцев Е. А. Полвека земской деятельно- сти по народному образованию. Москва: Задруга, 1915.96 с.

5. Иконников С. А. Деятельность российского приходского духовенства по созданию церковно-приходских школ во второй половине XIX - начале XX вв. Вестник ПСТГУ. Серия II: История. История Русской Православной Церкви. 2014. Вып. 6(61). С. 58-72.

6. Инструкция Екатеринославского губернського училищного совета для Попечителей начальних народних училищ. Сборник докладов и постановлений Земства Мариупольского уезда по вопросу о народном образовании с 1874 nо 1877 год. Мариуполь: Типография Л. А. Залюбовского, 1877. С. 115-120.

7. Кабузан В. М. Заселение Новороссии в конце XVIII - пер. пол. XIX в. (1719-1858 гг.). Москва: Наука, 1976. 306 с.

8. Каптерев П.Ф. Народная школа, земство и правительство. URL: https://www.docsity. com/ru/narodnaya-shkola-zemstvo-ipravitelstvo/1142808/ (дата обращения: 22.09.2019).

9. Лохматова А. І. Катеринославське земство. Запоріжжя: Тандем-У, 1999. 200 с.

10. Мариуполь и его окрестности: Отчет об учебных экскурсиях Мариупольской Александровской гимназии / изд. почет. попечителя Д. А. Хараджаева. Мариуполь: Тип. А. А. Франтова, 1892. 328 с.

11. Національна стратегія розвитку освіти в Україні на період до 2021 року: схвалено Указом Президента України від 25.06.2013 р. № 344/2013. URL: http:/ / zakon3.rada.gov.ua/ laws/show/344/2013\#n10 (дата звернення 22.09.2019)

12. О низших ремесленных школах. 24 апреля 1895 г. Сборник постановлений по Министерству народного просвещения. Санкт-Петербург, 1898. T. 13. С. 1315-1346.

13. Первая всеобщая перепись населения Российской империи 1897 г.: в 89 т. Т. 13: Екатеринославская губерния. 1904. XIV / под ред. Н. А. Тройницкого; Центр. стат. ком. М-ва внутр. дел. Санкт-Петербург, 1897-1905.

14. Пєнов В. Історичні особливості культурноосвітнього розвитку Півдня України в XIX на початку XX ст. Витоки педагогічної майстерності. Серія: Педагогічні науки. 2016. Вип. 18. С. 275-282. URL: http://nbuv.gov.ua/ UJRN/vpm_2016_18_49 (дата звернення 22.09.2019).

15. Правдюк О. В. Освіта менонітів у контексті культурного розвитку півдня України (XIX 20-ті pp. XX ст.): автореф. дис. ... канд. пед. наук: 13.00.01. Київ, 2011. 20 с.

16. Рудницька Н. В. Професійна освіта євреїв Волині у XIX - на початку XX ст. Український 
історичний журнал. 2001. № 6. С. 123-132.

17. Сараєва О. В. Земства Донбасу у системі владних і суспільних відносин пореформеної доби: монографія. Маріуполь: ДВНЗ «ПДТУ», 2013. 345 c.

18. Успехи грамотности в Мариупольском уезде. Приазовский край. 1891. 14 ноября.

\section{REFERENCES}

1. Ermolov, V. V. (2009). Osobennosti sistemy obrazovaniya v nacionalnyh shkolah Rossiyskoy imperii: nemeckie shkoly. Obshchestvo. Sreda. Razvitie, 3, 81-88 [in Russian].

2. Yefymov, D. V. (2016). Zemska reforma ta yii vplyv na rozvytok narodnoi osvity Donbasu $u$ druhii polovyni XIX - na pochatku XX st. Pedahohichni nauky: teoriia, istoriia, innovatsiini tekhnolohii, 2(56), 253-262 [in Ukrainian].

3. Zaslushan doklad komissii dlya razrabotki osnovaniy sooruzheniya narodnyh shkol. $1874 \mathrm{~g}$. (1916). Sistematicheskiy sbornik postanovleniy Mariupolskogo uezdnogo zemstva s 1869 po 1913 gg. (Vols. 1-2: Vol. 2) Moskva: Jelek.-Tipogr. Br. Je. i A. Goldrin, 80-81 [in Russian].

4. Zvyagincev, E. A. (1915). Polveka zemskoy deyatelnosti po narodnomu obrazovaniyu Moskva: Zadruga [in Russian].

5. Ikonnikov, S. A. (2014). Deyatelnost rossiyskogo prihodskogo duhovenstva po sozdaniyu cerkovno-prihodskih shkol vo vtoroy polovine XIX - nachale XX vv. Vestnik PSTGU. Seriya II: Istoriya. Istoriya Russkoy Pravoslavnoy Cerkvi, 6(61), 58-72 [in Russian].

6. Instrukciya Ekaterinoslavskogo gubernskogo uchilishchnogo soveta dlya Popechiteley nachalnyh narodnyh uchilishch (1877). Sbornik dokladov i postanovleniy Zemstva Mariupolskogo uezda po voprosu o narodnom obrazovanii s 1874 po 1877 god. Mariupol: Tipografiya L. A. Zalyubovskogo. 115-120 [in Russian].

7. Kabuzan, V. M. (1976). Zaselenie Novorossii v konce XVIII - per. pol. XIX v. (1719-1858 gg.). Moskva: Nauka [in Russian].

8. Kapterev, P. F. Narodnaya shkola, zemstvo i pravitelstvo. URL: https://www.docsity.com/ ru/narodnaya-shkola-zemstvo-i-pravitelstvo/

1142808/ [in Russian].

9. Lokhmatova, A. I. (1999). Katerynoslavske zemstvo. Zaporizhzhia: Tandem-U [in Ukrainian].

10. Mariupol i ego okrestnosti: Otchet ob uchebnyh ekskursiyah Mariupolskoy Aleksandrovskoy gimnazii (1892) / Izd. pochet. Popechitelya D. A. Haradzhaeva. Mariupol: Tip. A. A. Frantova [in Russian].

11. Natsionalna stratehiia rozvytku osvity v Ukraini na period do 2021 roku: skhvaleno Ukazom Prezydenta Ukrainy vid 25.06.2013 r. № 344/2013. URL: http:/ / zakon3.rada.gov. ua/laws/show/344/2013\#n10 [in Ukrainian].

12. O nizshih remeslennyh shkolah. 24 aprelya 1895 g. (1898). Sbornik postanovleniy po Ministerstvu narodnogo prosveshcheniya. Vol. 13. SanktPeterburg, 1315-1346 [in Russian].

13. Pervaya vseobshchaya perepis naseleniya Rossiyskoy imperii 1897 g. (1904). (Vols. 89): Vol. 13: Ekaterinoslavskaya guberniya. XIV. N. A. Troynickiy (Ed.). Sankt-Peterburg, 18971905 [in Russian].

14. Pienov, V. (2016). Istorychni osoblyvosti kulturno-osvitnioho rozvytku Pivdnia Ukrainy v XIX - na pochatku XX st. Vytoky pedahohichnoi maisternosti. Seriia: Pedahohichni nauky, 18, 275-282. URL: http://nbuv.gov.ua/UJRN/ vpm_2016_18_49 [in Ukrainian].

15. Pravdiuk, O. V. (2011). Osvita menonitiv u konteksti kulturnoho rozvytku pivdnia Ukrainy (XIX - 20-ti rr. XX st.). Extended abstract of candidate's thesis. Kyiv [in Ukrainian].

16. Rudnytska, N. V. (2001). Profesiina osvita yevreiv Volyni u XIX - na pochatku XX st. Ukrainskyi istorychnyi zhurnal, 6, 123-132 [in Ukrainian].

17. Saraieva, O. V. (2013). Zemstva Donbasu u systemi vladnykh i suspilnykh vidnosyn poreformenoi doby. Mariupol: PDTU [in Ukrainian].

18. Uspehi gramotnosti v Mariupolskom uezde. (1891). Priazovskiy kray. 14 noyabrya [in Russian]. 